\title{
Glycocalyx as Possible Limiting Factor in COVID-19
}

\author{
Patricia P. Wadowski ${ }^{1 *}$, Bernd Jilma ${ }^{2}$, Christoph W. Kopp ${ }^{1}$, Sebastian Ertl ${ }^{1,2}$, \\ Thomas Gremmel ${ }^{1,3}$ and Renate Koppensteiner ${ }^{1}$ \\ ${ }^{1}$ Division of Angiology, Department of Internal Medicine II, Medical University of Vienna, Vienna, Austria, ${ }^{2}$ Department of \\ Clinical Pharmacology, Medical University of Vienna, Vienna, Austria, ${ }^{3}$ Department of Internal Medicine I, Landesklinikum \\ Mistelbach-Gänserndorf, Mistelbach, Austria
}

Keywords: glycocalyx, heparan sulfate, complement, SARS-CoV-2, COVID-19

\section{OPEN ACCESS}

Edited by:

Deirdre R. Coombe,

Curtin University, Australia

Reviewed by:

John Tarbell,

City College of New York (CUNY),

United States

Rupert Hallmann,

University of Münster, Germany

${ }^{*}$ Correspondence:

Patricia P. Wadowsk patricia.wadowski@meduniwien.ac.at

Specialty section

This article was submitted to Inflammation,

a section of the journal

Frontiers in Immunology

Received: 18 September 2020 Accepted: 28 January 2021

Published: 22 February 2021

Citation:

Wadowski PP, Jilma B, Kopp CW,

Ertl S, Gremmel T and Koppensteiner R (2021) Glycocalyx as Possible Limiting Factor in COVID-19.

Front. Immunol. 12:607306.

doi: 10.3389/fimmu.2021.607306
The coronavirus disease 2019 (COVID-19) has emerged as a global burden comprising cardiovascular and respiratory complications. Herein, endothelial cell infection causing endotheliitis is discussed as a key mechanism. However, knowledge on underlying molecular pathways is still scarce. In this opinion we would like to highlight the role of glycocalyx disturbance for endothelial cell infection possibly being the limiting factor to SARS-CoV-2 disease exacerbation.

Besides the development of an acute respiratory distress syndrome (ARDS) in patients who are critically ill after infection with SARS-CoV-2, endothelial dysfunction seems to be an underlying cause of multiorgan failure. In fact, SARS- CoV-2 directly infects human vascular organoids in vitro (1) and autopsy studies of patients dying from coronavirus disease 2019 (COVID-19) show severe endothelial cell damage with disrupted cell membranes, intracellular virus and endotheliitis $(2,3)$.

The glycocalyx is a key regulator of endothelial cell homeostasis, tissue oedema and inflammatory processes (4). It consists of membrane-bound proteoglycans and glycoproteins and covers endothelial cells at the luminal vessel side $(4,5)$. Together with adsorbed molecules from the blood plasma, the glycocalyx forms the endothelial surface layer (4). This fragile barrier is disturbed in inflammatory processes (6) and cardiovascular diseases (7-9) being associated with patient outcome (10-12). Recently, it was shown that glycocalyx thickness is predictive of mortality in septic patients, with higher perfused boundary regions (PBR) measured within $24 \mathrm{~h}$ after ICU admission in non-survivors (12). Perfused boundary regions were visualized using sublingual non-invasive sidestream-darkfield imaging and used as an indirect and inverse marker of the glycocalyx (12).

In addition, during septic shock, plasma levels of glycosaminoglycans (GAGs) increase suggesting glycocalyx destruction $(6,13)$ with higher plasma levels of hyaluronan and heparan sulfate (HS) in non-survivors (6). Similarly, urinary levels of hyaluronic acid and HS are higher in non-surviving patients (10). Furthermore, the levels of urinary GAGs predicted the development and progression of renal dysfunction in patients with septic shock and were also associated with in-hospital mortality in patients with ARDS (10). Finally, another component of the glycocalyx, syndecan-1, is elevated continuously in septic non-survivors, while it decreases during the course of the disease in surviving patients (14).

The current SARS-CoV-2 induced COVID-19 is associated with similar patterns of disease exacerbation, namely sepsis, renal failure, and $\operatorname{ARDS}(3,15)$. Since the glycocalyx has a main role in the development of tissue oedema according to the Starling equation, it has been postulated that glycocalyx disintegrity impacts the development of ARDS (16).

Intriguingly, beside binding to angiotensin-converting enzyme 2 (ACE2) (17), SARS-CoV needs HS, the major component of GAGs in the glycocalyx (18), as adhesion molecule (19). The suggested binding site of HS is constituted of positively charged amino acid residues at the receptor-binding domain adjacent to the ACE-2 binding site (20). 
SARS-CoV has a similarity to human coronavirus NL63 (HCoV-NL63), an alphacoronavirus, which also uses ACE2 and HS for cellular entry (21). In fact, HS proteoglycans act as adhesion molecules thereby increasing HCoV-NL63 density on the cellular surface (21). The use of glycans as attachment (co-) factors is also observed in the initial interaction of numerous viruses with host cells (22).

The influenza virus, adenovirus, rotavirus, and reovirus bind to sialic acid via stalk-like attachment proteins (23). Herpes simplex virus type 1 (HSV-1) uses galectin-3 as entry mediator (24). In addition, HSV-1 cellular entry depends on $\mathrm{HS}$ and especially 3-O-sulfation of specific HS glucosamine residues (25). For HSV-2 the HS entry site is virtually inactive (26). Both HSV-1 and HSV-2 use nectin-1, which interacts with the glycosaminoglycans of the glycocalyx, as entry receptor (26).

Human immunodeficiency virus 1 (HIV-1) binds to $\mathrm{HS}$ in a complex manner, where HS can promote viral attachment and transcytosis through epithelia (27). A specific CD4HS glycoconjugate has been developed to inhibit HIV-1 attachment (27).

In addition, enteroviruses use HS for attachment to host cells (28-30). HS binding is also used by different hepatitis viruses (31-33), human papillomavirus $(34)$, polyomaviruses $(35,36)$, rhinoviruses (36-38) and coxsackie viruses $(39,40)$.

Finally, also arthropod-borne viruses like the chikungunya, yellow fever, Japanese and Murray Valley encephalitis virus, eastern equine encephalitis virus, West $\mathrm{Nil}$ and Dengue virus are dependent on the glycocalyx as entry site (41-48).

This finding is surprising, as it questions the protective role of the glycocalyx. However, for HCoV-NL63 these observations were seen in vitro among others by adding HS proteoglycans to the cell culture (21). In vivo, glycocalyx degradation and release of soluble HS is part of the innate immunity, as it is recognized as danger- associated molecular pattern (DAMP), hereby promoting an inflammatory burst by tolllike receptor interaction (49). Hence glycocalyx destruction seems to mediate severe COVID-19. Recently, Stahl et al. demonstrated that COVID-19 patients experience an acquired loss of the protective heparanase 2 and an increase in PBR (50). However, future research should be conducted to give further insights into the natural course of disease pathology and the role of HS. In addition, current studies should emphasize on mutations in the receptor-binding domain of SARS-CoV-2 as for e.g., the N501Y mutation (51) and potential effects on HS binding.

The glycocalyx is a very fragile structure, regulated by shear forces and strongly susceptible to environmental changes (4). Therefore, it has for years been underestimated, because applied staining protocols degraded its structure (4). Furthermore, the endothelial layer is determined by the interaction of the glycocalyx with different plasma proteins (4). In cell cultures, glycocalyx formation is modified by cell type, cellular density, culture conditions and shear stress (52). The latter influences glycocalyx structure and composition (52). Viral cell entry of SARS pseudovirus was reported to be inhibited by lactoferrin, which binds to HS (19).
Hence we assume that glycocalyx disintegrity accounts for enhanced viral entry. It is known, that inflammatory conditions lead to severe glycocalyx modulations, including the shedding of its components like HS, chondroitin sulfate or syndecan and glypican core proteins with attached GAGs (52). Recent reports suggest enhanced heparanase activity in more severe COVID-19 disease (53).

Further, glycocalyx shedding can be conferred by cytokines and chemoattractants $(52,54)$. The latter, i.e., the complement system was discussed as key factor in SARS- CoV-2 mediated ARDS (55).

Activation of the complement cascade develops 1 day after SARS-CoV infection (56). Herein, activation of C3 has a key role in disease exacerbation, as C3 deficient mice experienced less respiratory dysfunction and weight loss (56).

Following extensive modifications by D-glycuronyl C5epimerase and 2-O-, 3-O-, and 6-O-sulfotransferases $\mathrm{HS}$ is characterized by a heterogenous structure (57). HS structural variability accounts for e.g., for either activation or inhibition of the complement system (57). The grade of sulphation determines C3b cleaving, which is accelerated by HS with lower sulphation (58).

Potential therapeutic approaches include the administration of the glycoprotein SPARC, which has been reported to restore the glycocalyx in coxsackievirus-B3 induced myocarditis (59). Further, albumin infusions have been shown to preserve the glycocalyx and mediate its recovery $(60,61)$. Albumin carries sphingosine-1 phosphate to the endothelium, which inhibits syndecan-1 shedding (62). Further, rhamnan sulfate, a polysaccharide extracted from the green algae M. nitidum has antiviral and antithrombotic properties $(63,64)$. Sevoflurane, which is used during anesthesia, has been shown to be protective against ischemia- reperfusion injury of the glycocalyx (65). Recently, liposomal nanocarriers with pre-assembled glycocalyx have been developed and shown to restore NO- production in heparanase III -treated endothelial cells $(64,66)$. Another therapeutic opportunity includes an anti-adhesive coating of the glycocalyx, consisting of a dermatan sulfate backbone with multiple selectin- binding peptides, which prevents platelet binding to inflamed endothelium (67). This coating reduced in vivo thrombus formation in a mouse model of deep vein thrombosis (67).

Heparin, which is closely related to HS has further been speculated to be protective, while binding SARS-CoV-2 and inducing its conformational change (68). Further, heparin acts as heparanase inhibitor (11). However, the grade of sulphation might limit its beneficial effects regarding C3b cleavage and complement activation (58). In addition, heparin interferes with the binding of antithrombin III to the glycocalyx (69). Antithrombin III is known to reduce inflammation (69-71) and to protect the glycocalyx from enzymatic degradation (69).

Another heparanase inhibitor, sulodexide, which is a glycosaminoglycan extracted from porcine intestinal mucosa, was already applied in patients with type 2 diabetes and increased retinal and sublingual glycocalyx thickness $(11,72)$.

In pre-clinical models the application of atrasentan, a selective endothelin A receptor antagonist, increased glycocalyx 
dimensions, NO concentrations and reduced heparanase expression and albuminuria (73).

As the inflammatory response is more and more regarded as crucial in COVID-19 exacerbation, the use of steroids, might be helpful to preserve glycocalyx structure in severe cases (7476). The application of dexamethasone is already recommended in patients who require supplemental oxygen or mechanical ventilation (77). However, adverse effects on glycocalyx structure and endothelial permeability of steroid application have also been reported $(78,79)$.

In summary, though to date knowledge on SARS-CoV2 pathogenesis is still scarce, histological findings show

\section{REFERENCES}

1. Monteil V, Kwon H, Prado P, Hagelkruys A, Wimmer RA, Stahl M, et al. Inhibition of SARS-CoV-2 infections in engineered human tissues using clinical-grade soluble human ACE2. Cell. (2020) 181:905-13.e7. doi: 10.1016/j.cell.2020.04.004

2. Ackermann M, Verleden SE, Kuehnel M, Haverich A, Welte T, Laenger F, et al. Pulmonary vascular endothelialitis, thrombosis, and angiogenesis in covid-19. N Engl J Med. (2020) 383:120-8. doi: 10.1056/NEJMoa2015432

3. Varga Z, Flammer AJ, Steiger P, Haberecker M, Andermatt R, Zinkernagel AS, et al. Endothelial cell infection and endotheliitis in COVID-19. Lancet. (2020) 395:1417-8. doi: 10.1016/S0140-6736(20)30937-5

4. Reitsma S, Slaaf DW, Vink H, van Zandvoort MA, oude Egbrink MG. The endothelial glycocalyx: composition, functions, and visualization. Pflugers Archiv. (2007) 454:345-59. doi: 10.1007/s00424-007-0212-8

5. Pries AR, Secomb TW, Gaehtgens P. The endothelial surface layer. Pflugers Archiv. (2000) 440:653-66. doi: 10.1007/s004240000307

6. Nelson A, Berkestedt I, Bodelsson M. Circulating glycosaminoglycan species in septic shock. Acta Anaesthesiol Scand. (2014) 58:36-43. doi: 10.1111/aas.12223

7. van den Berg BM, Vink H, Spaan JA. The endothelial glycocalyx protects against myocardial edema. Circ Res. (2003) 92:592-4. doi: 10.1161/01.RES.0000065917.53950.75

8. Wadowski PP, Kautzky-Willer A, Gremmel T, Koppensteiner R, Wolf P, Ertl S, et al. Sublingual microvasculature in diabetic patients. Microvasc Res. (2020) 129:103971. doi: 10.1016/j.mvr.2019.103971

9. Salmon AH, Satchell SC. Endothelial glycocalyx dysfunction in disease: albuminuria and increased microvascular permeability. J Pathol. (2012) 226:562-74. doi: 10.1002/path.3964

10. Schmidt EP, Overdier KH, Sun X, Lin L, Liu X, Yang Y, et al. Urinary glycosaminoglycans predict outcomes in septic shock and acute respiratory distress syndrome. Am J Respir Crit Care Med. (2016) 194:439-49. doi: 10.1164/rccm.201511-2281OC

11. Uchimido R, Schmidt EP, Shapiro NI. The glycocalyx: a novel diagnostic and therapeutic target in sepsis. Crit Care. (2019) 23:16. doi: 10.1186/s13054-018-2292-6

12. Beurskens DM, Bol ME, Delhaas T, van de Poll MC, Reutelingsperger CP, Nicolaes GA, et al. Decreased endothelial glycocalyx thickness is an early predictor of mortality in sepsis. Anaesth Intensive Care. (2020) 48:310057X20916471. doi: 10.1177/0310057X20916471

13. Henrich M, Gruss M, Weigand MA. Sepsis-induced degradation of endothelial glycocalix. Sci World J. (2010) 10:917-23. doi: 10.1100/tsw. 2010.88

14. Anand D, Ray S, Srivastava LM, Bhargava S. Evolution of serum hyaluronan and syndecan levels in prognosis of sepsis patients. Clin Biochem. (2016) 49:768-76. doi: 10.1016/j.clinbiochem.2016. 02.014

15. Ronco C, Reis T, Husain-Syed F. Management of acute kidney injury in patients with COVID-19. Lancet Respir Med. (2020) 8:738-42. doi: $10.1016 / \mathrm{S} 2213-2600(20) 30229-0$ endotheliitis and recent in vivo measurements suggest endothelial dysfunction as integral element in severe COVID-19 $(2,3,50)$.

In consequence we would like to urge researchers to focus on preservation models for glycocalyx composition to enhance benefits for patient outcome.

\section{AUTHOR CONTRIBUTIONS}

All authors listed have made a substantial, direct and intellectual contribution to the work, and approved it for publication.

16. Collins SR, Blank RS, Deatherage LS, Dull RO. Special article: the endothelial glycocalyx: emerging concepts in pulmonary edema and acute lung injury. Anesth Analg. (2013) 117:664-74. doi: 10.1213/ANE.0b013e3182975b85

17. Vaduganathan M, Vardeny O, Michel T, McMurray JJV, Pfeffer MA, Solomon SD. Renin-angiotensin-aldosterone system inhibitors in patients with covid-19. N Engl J Med. (2020) 382:1653-9. doi: 10.1056/NEJMsr 2005760

18. Oohira A, Wight TN, Bornstein P. Sulfated proteoglycans synthesized by vascular endothelial cells in culture. J Biol Chem. (1983) 258:2014-21. doi: 10.1016/S0021-9258(18)33090-4

19. Lang J, Yang N, Deng J, Liu K, Yang P, Zhang G, Jiang C. Inhibition of SARS pseudovirus cell entry by lactoferrin binding to heparan sulfate proteoglycans. PLoS ONE. (2011) 6:e23710. doi: 10.1371/journal.pone.0023710

20. Clausen TM, Sandoval DR, Spliid CB, Pihl J, Perrett HR, Painter CD, et al. SARS-CoV-2 infection depends on cellular heparan sulfate and ACE2. Cell. (2020) 183:1043-1057.e15. doi: 10.1101/2020.07.14.201616

21. Milewska A, Zarebski M, Nowak P, Stozek K, Potempa J, Pyrc K. Human coronavirus NL63 utilizes heparan sulfate proteoglycans for attachment to target cells. J Virol. (2014) 88:13221-30. doi: 10.1128/JVI.02078-14

22. Cagno V, Tseligka ED, Jones ST, Tapparel C. Heparan sulfate proteoglycans and viral attachment: true receptors or adaptation bias? Viruses. (2019) 11:596. doi: $10.3390 / \mathrm{v} 11070596$

23. Stencel-Baerenwald JE, Reiss K, Reiter DM, Stehle T, Dermody TS. The sweet spot: defining virus-sialic acid interactions. Nat Rev Microbiol. (2014) 12:739-49. doi: 10.1038/nrmicro3346

24. Woodward AM, Mauris J, Argüeso P. Binding of transmembrane mucins to galectin-3 limits herpesvirus 1 infection of human corneal keratinocytes. $J$ Virol. (2013) 87:5841-7. doi: 10.1128/JVI.00166-13

25. Shukla D, Liu J, Blaiklock P, Shworak NW, Bai X, Esko JD, et al. A novel role for 3-O-sulfated heparan sulfate in herpes simplex virus 1 entry. Cell. (1999) 99:13-22. doi: 10.1016/S0092-8674(00)80058-6

26. Spear PG. Herpes simplex virus: receptors and ligands for cell entry. Cell Microbiol. (2004) 6:401-10. doi: 10.1111/j.1462-5822.2004.00389.x

27. Connell BJ, Lortat-Jacob H. Human immunodeficiency virus and heparan sulfate: from attachment to entry inhibition. Front Immunol. (2013) 4:385. doi: 10.3389 /fimmu.2013.00385

28. Israelsson S, Gullberg M, Jonsson N, Roivainen M, Edman K, Lindberg AM. Studies of Echovirus 5 interactions with the cell surface: heparan sulfate mediates attachment to the host cell. Virus Res. (2010) 151:170-6. doi: 10.1016/j.virusres.2010.05.001

29. Goodfellow IG, Sioofy AB, Powell RM, Evans DJ. Echoviruses bind heparan sulfate at the cell surface. J Virol. (2001) 75:4918. doi: 10.1128/JVI.75.10.4918-4921.2001

30. Tseligka ED, Sobo K, Stoppini L, Cagno V, Abdul F, Piuz I, et al. A VP1 mutation acquired during an enterovirus 71 disseminated infection confers heparan sulfate binding ability and modulates ex vivo tropism. PLoS Pathog. (2018) 14:e1007190. doi: 10.1371/journal.ppat.1007190

31. Lamas Longarela O, Schmidt TT, Schöneweis K, Romeo R, Wedemeyer H, Urban S, et al. Proteoglycans act as cellular hepatitis delta virus attachment receptors. PLoS ONE. (2013) 8:e58340. doi: 10.1371/journal.pone.0058340 
32. Leistner CM, Gruen-Bernhard S, Glebe D. Role of glycosaminoglycans for binding and infection of hepatitis B virus. Cell Microbiol. (2008) 10:122-33. doi: 10.1111/j.1462-5822.2007.01023.x

33. Xu Y, Martinez P, Séron K, Luo G, Allain F, Dubuisson J, et al. Characterization of hepatitis $\mathrm{C}$ virus interaction with heparan sulfate proteoglycans. J Virol. (2015) 89:3846. doi: 10.1128/JVI.03647-14

34. Giroglou T, Florin L, Schäfer F, Streeck RE, Sapp M. Human papillomavirus infection requires cell surface heparan sulfate. J Virol. (2001) 75:1565. doi: 10.1128/JVI.75.3.1565-1570.2001

35. Schowalter RM, Pastrana DV, Buck CB. Glycosaminoglycans and sialylated glycans sequentially facilitate Merkel cell polyomavirus infectious entry. PLoS Pathog. (2011) 7:e1002161. doi: 10.1371/journal.ppat.1002161

36. Khan AG, Pickl-Herk A, Gajdzik L, Marlovits TC, Fuchs R, Blaas D. Entry of a heparan sulphate-binding HRV8 variant strictly depends on dynamin but not on clathrin, caveolin, and flotillin. Virology. (2011) 412:55-67. doi: 10.1016/j.virol.2010.12.042

37. Bochkov YA, Watters K, Basnet S, Sijapati S, Hill M, Palmenberg $\mathrm{AC}$, et al. Mutations in VP1 and 3A proteins improve binding and replication of rhinovirus C15 in HeLa-E8 cells. Virology. (2016) 499:350-60. doi: 10.1016/j.virol.2016.09.025

38. Vlasak M, Goesler I, Blaas D. Human rhinovirus type 89 variants use heparan sulfate proteoglycan for cell attachment. J Virol. (2005) 79:5963. doi: 10.1128/JVI.79.10.5963-5970.2005

39. Zhang X, Shi J, Ye X, Ku Z, Zhang C, Liu Q, et al. Coxsackievirus A16 utilizes cell surface heparan sulfate glycosaminoglycans as its attachment receptor. Emerg Microbes Infect. (2017) 6:e65. doi: 10.1038/emi.2017.55

40. Wang Y, Pfeiffer JK. Emergence of a large-plaque variant in mice infected with coxsackievirus B3. mBio. (2016) 7:e00119-16. doi: 10.1128/mBio.00119-16

41. Schwameis M, Buchtele N, Wadowski PP, Schoergenhofer C, Jilma B. Chikungunya vaccines in development. Hum Vaccin Immunother. (2016) 12:716-31. doi: 10.1080/21645515.2015.1101197

42. Silva LA, Khomandiak S, Ashbrook AW, Weller R, Heise MT, Morrison TE, et al. A single-amino-acid polymorphism in chikungunya virus E2 glycoprotein influences glycosaminoglycan utilization. J Virol. (2014) 88:2385. doi: 10.1128/JVI.03116-13

43. Gardner CL, Hritz J, Sun C, Vanlandingham DL, Song TY, Ghedin E, et al. Deliberate attenuation of chikungunya virus by adaptation to heparan sulfatedependent infectivity: a model for rational arboviral vaccine design. PLoS Negl Trop Dis. (2014) 8:e2719. doi: 10.1371/journal.pntd.0002719

44. Fernandez-Garcia MD, Meertens L, Chazal M, Hafirassou ML, Dejarnac O, Zamborlini A, et al. Vaccine and wild-type strains of yellow fever virus engage distinct entry mechanisms and differentially stimulate antiviral immune responses. mBio. (2016) 7:e01956-15. doi: 10.1128/mBio.01956-15

45. Lee E, Hall RA, Lobigs M. Common E protein determinants for attenuation of glycosaminoglycan-binding variants of Japanese encephalitis and west nile viruses. J Virol. (2004) 78:8271. doi: 10.1128/JVI.78.15.8271-8280.2004

46. Gardner CL, Ebel GD, Ryman KD, Klimstra WB. Heparan sulfate binding by natural eastern equine encephalitis viruses promotes neurovirulence. Proc Natl Acad Sci. (2011) 108:16026. doi: 10.1073/pnas.1110617108

47. Artpradit C, Robinson LN, Gavrilov BK, Rurak TT, Ruchirawat M, Sasisekharan R. Recognition of heparan sulfate by clinical strains of dengue virus serotype 1 using recombinant subviral particles. Virus Res. (2013) 176:69-77. doi: 10.1016/j.virusres.2013.04.017

48. Lee E, Lobigs M. Mechanism of virulence attenuation of glycosaminoglycanbinding variants of japanese encephalitis virus and murray valley encephalitis virus. J Virol. (2002) 76:4901. doi: 10.1128/JVI.76.10.4901-4911.2002

49. Simon Davis DA, Parish CR. Heparan sulfate: a ubiquitous glycosaminoglycan with multiple roles in immunity. Front Immunol. (2013) 4:470. doi: 10.3389/fimmu.2013.00470

50. Stahl K, Gronski PA, Kiyan Y, Seeliger B, Bertram A, Pape T, et al. Injury to the endothelial glycocalyx in critically ill patients with COVID-19. Am J Respir Crit Care Med. (2020) 202:1178-81. doi: 10.1164/rccm.202007-2676LE

51. Leung K, Shum MH, Leung GM, Lam TT, Wu JT. Early transmissibility assessment of the N501Y mutant strains of SARS-CoV-2 in the United Kingdom, October to November 2020. Euro Surveill. (2021) 26:2002106. doi: 10.2807/1560-7917.ES.2020.26.1.2002106

52. Kolarova H, Ambruzova B, Svihalkova Sindlerova L, Klinke A, Kubala L. Modulation of endothelial glycocalyx structure under inflammatory conditions. Mediators Inflamm. (2014) 2014:694312. doi: $10.1155 / 2014 / 694312$

53. Buijsers B, Yanginlar C, Grondman I, de Nooijer A, Maciej-Hulme ML, Jonkman I, et al. Increased plasma heparanase activity in COVID-19 patients. medRxiv. (2020). doi: 10.1101/2020.06.12.20129304

54. Chappell D, Westphal M, Jacob M. The impact of the glycocalyx on microcirculatory oxygen distribution in critical illness. Curr Opin Anaesthesiol. (2009) 22:155-62. doi: 10.1097/ACO.0b013e32832 $8 \mathrm{~d} 1 \mathrm{~b} 6$

55. Risitano AM, Mastellos DC, Huber-Lang M, Yancopoulou D, Garlanda C, Ciceri F, et al. Complement as a target in COVID-19? Nat Rev Immunol. (2020) 20:343-4. doi: 10.1038/s41577-020-0320-7

56. Gralinski LE, Sheahan TP, Morrison TE, Menachery VD, Jensen K, Leist SR, et al. Complement activation contributes to severe acute respiratory syndrome coronavirus pathogenesis. mBio. (2018) 9:e01753-18. doi: $10.1128 / \mathrm{mBio} .01753-18$

57. Collins LE, Troeberg L. Heparan sulfate as a regulator of inflammation and immunity. J Leukoc Biol. (2019) 105:81-92. doi: 10.1002/JLB.3RU0618-246R

58. Kelly U, Yu L, Kumar P, Ding JD, Jiang H, Hageman GS, et al. Heparan sulfate, including that in Bruch's membrane, inhibits the complement alternative pathway: implications for age-related macular degeneration. J Immunol. (2010) 185:5486-94. doi: 10.4049/jimmunol.0903596

59. Rienks M, Carai P, van Teeffelen J, Eskens B, Verhesen W, Hemmeryckx B, et al. SPARC preserves endothelial glycocalyx integrity, and protects against adverse cardiac inflammation and injury during viral myocarditis. Matrix Biol. (2018) 74:21-34. doi: 10.1016/j.matbio.2018.04.015

60. Kozar RA, Peng Z, Zhang R, Holcomb JB, Pati S, Park P, et al. Plasma restoration of endothelial glycocalyx in a rodent model of hemorrhagic shock. Anesth Analg. (2011) 112:1289-95. doi: 10.1213/ANE.0b013e318210385c

61. Jacob M, Paul O, Mehringer L, Chappell D, Rehm M, Welsch U, et al. Albumin augmentation improves condition of guinea pig hearts after $4 \mathrm{hr}$ of cold ischemia. Transplantation. (2009) 87:956-65. doi: 10.1097/TP.0b013e31819c83b5

62. Zeng Y, Adamson RH, Curry FR, Tarbell JM. Sphingosine-1phosphate protects endothelial glycocalyx by inhibiting syndecan-1 shedding. Am J Physiol Heart Circ Physiol. (2014) 306:H363-72. doi: 10.1152/ajpheart.00687.2013

63. Suzuki K, Terasawa M. Biological activities of rhamnan sulfate extract from the green algae monostroma nitidum (Hitoegusa). Mar Drugs. (2020) 18:228. doi: $10.3390 / \mathrm{md} 18040228$

64. Weinbaum S, Cancel LM, Fu BM, Tarbell JM. The glycocalyx and its role in vascular physiology and vascular related diseases. Cardiovasc Eng Technol. (2020). doi: 10.1007/s13239-020-00485-9. [Epub ahead of print].

65. Annecke T, Chappell D, Chen C, Jacob M, Welsch U, Sommerhoff CP, et al. Sevoflurane preserves the endothelial glycocalyx against ischaemiareperfusion injury. Br J Anaesth. (2010) 104:414-21. doi: 10.1093/bja/ aeq019

66. Zhang X, Sun D, Song JW, Zullo J, Lipphardt M, Coneh-Gould L, et al. Endothelial cell dysfunction and glycocalyx - a vicious circle. Matrix Biol. (2018) 71-72:421-31. doi: 10.1016/j.matbio.2018.01.026

67. Wodicka JR, Chambers AM, Sangha GS, Goergen CJ, Panitch A. Development of a glycosaminoglycan derived, selectin targeting anti-adhesive coating to treat endothelial cell dysfunction. Pharmaceuticals (Basel). (2017) 10:36. doi: $10.3390 / \mathrm{ph} 10020036$

68. Mycroft-West C, Su D, Elli S, Li Y, Guimond S, Miller G, et al. The 2019 coronavirus (SARS-CoV-2) surface protein (Spike) S1 receptor binding domain undergoes conformational change upon heparin binding. bioRxiv [Preprint]. (2020). doi: 10.1101/2020.02.29.971093

69. Becker BF, Chappell D, Bruegger D, Annecke T, Jacob M. Therapeutic strategies targeting the endothelial glycocalyx: acute deficits, but great potential. Cardiovasc Res. (2010) 87:300-10. doi: 10.1093/cvr/cvq137

70. Afshari A, Wetterslev J, Brok J, Moller AM. Antithrombin III for critically ill patients. Cochrane Database Syst Rev. (2008) CD005370. doi: 10.1002/14651858.CD005370.pub2

71. Leitner JM, Firbas C, Mayr FB, Reiter RA, Steinlechner B, Jilma B. Recombinant human antithrombin inhibits thrombin formation and interleukin 6 release in human endotoxemia. Clin Pharmacol Ther. (2006) 79:23-34. doi: 10.1016/j.clpt.2005.10.003 
72. Broekhuizen LN, Lemkes BA, Mooij HL, Meuwese MC, Verberne H, Holleman F, et al. Effect of sulodexide on endothelial glycocalyx and vascular permeability in patients with type 2 diabetes mellitus. Diabetologia. (2010) 53:2646-55. doi: 10.1007/s00125-010-1910-x

73. Boels MG, Avramut MC, Koudijs A, Dane MJ, Lee DH, van der Vlag J, et al. Atrasentan reduces albuminuria by restoring the glomerular endothelial glycocalyx barrier in diabetic nephropathy. Diabetes. (2016) 65:2429-39. doi: $10.2337 / \mathrm{db} 15-1413$

74. Chappell D, Jacob M, Hofmann-Kiefer K, Bruegger D, Rehm M, Conzen P, et al. Hydrocortisone preserves the vascular barrier by protecting the endothelial glycocalyx. Anesthesiology. (2007) 107:776-84. doi: 10.1097/01.anes.0000286984.39328.96

75. Brettner F, Chappell D, Nebelsiek T, Hauer D, Schelling G, Becker $\mathrm{BF}$, et al. Preinterventional hydrocortisone sustains the endothelial glycocalyx in cardiac surgery. Clin Hemorheol Microcirc. (2019) 71:59-70. doi: $10.3233 / \mathrm{CH}-180384$

76. Chappell D, Dorfler N, Jacob M, Rehm M, Welsch U, Conzen $\mathrm{P}$, et al. Glycocalyx protection reduces leukocyte adhesion after ischemia/reperfusion. Shock. (2010) 34:133-9. doi: 10.1097/SHK.0b013e3181c dc363

77. COVID-19 Treatment Guidelines Panel Coronavirus Disease 2019 (COVID19) Treatment Guidelines National Institutes of Health. Available online at: https://wwwcovid19treatmentguidelinesnihgov/ (accessed December 07, 2020).

78. Yoneda K, Walzer PD. The effect of corticosteroid treatment on the cell surface glycocalyx of the rat pulmonary alveolus: relevance to the hostparasite relationship in pneumocystis carinii infection. $\mathrm{Br} J$ Exp Pathol. (1984) 65:347-54

79. Kirsch T, Beese M, Wyss K, Klinge U, Haller H, Haubitz M, et al. Aldosterone modulates endothelial permeability and endothelial nitric oxide synthase activity by rearrangement of the actin cytoskeleton. Hypertension. (2013) 61:501-8. doi: 10.1161/HYPERTENSIONAHA.111.196832

Conflict of Interest: The authors declare that the research was conducted in the absence of any commercial or financial relationships that could be construed as a potential conflict of interest.

Copyright (C) 2021 Wadowski, Jilma, Kopp, Ertl, Gremmel and Koppensteiner. This is an open-access article distributed under the terms of the Creative Commons Attribution License (CC BY). The use, distribution or reproduction in other forums is permitted, provided the original author(s) and the copyright owner(s) are credited and that the original publication in this journal is cited, in accordance with accepted academic practice. No use, distribution or reproduction is permitted which does not comply with these terms. 